Article

\title{
The Effects of Organic and Mineral Fertilization on Soil Enzyme Activities and Bacterial Community in the Below- and Above-Ground Parts of Wheat
}

\author{
Abdoulaye Amadou ${ }^{D}$, Alin Song, Zhi-Xi Tang, Yanling Li, En-Zhao Wang, Yu-Qiu Lu, \\ Xiong-Duo Liu, Keke Yi, Bin Zhang and Fenliang Fan * \\ Key Laboratory of Plant Nutrition and Fertilization, Ministry of Agriculture, Institute of Agricultural Resources \\ and Regional Planning, Chinese Academy of Agricultural Sciences, Beijing 100081, China; \\ 2017Y90100156@caas.cn (A.A.); songalin@caas.cn (A.S.); tangzhixi@ibcas.ac.cn (Z.-X.T.); \\ liyanling_2015@163.com (Y.L.); enzhaowang@163.com (E.-Z.W.); luyuqiu_1106@163.com (Y.-Q.L.); \\ xd11112@163.com (X.-D.L.); yikeke@caas.cn (K.Y.); zhangbin01@caas.cn (B.Z.) \\ * Correspondence: fanfenliang@caas.cn
}

Received: 27 August 2020; Accepted: 18 September 2020; Published: 23 September 2020

check for updates

\begin{abstract}
Bacterial community and soil enzymatic activity depend on soil and management conditions. Fertilization is an important approach to maintain and enhance enzyme activities and microbial community diversity. Although the effects of fertilizer application on soil microbial community and related parameters are explored, the effects on the soil microbiome associated with those of wheat plant organs, including those associated with roots and spikelets, are not well-known. Therefore, in this study, by using a sequencing approach, we assessed the effects of inorganic fertilizers, manure, and biochar on soil enzyme activities, bacterial community diversity and structure in the bulk soil, rhizosphere, roots, and spikelet of wheat (Triticumaestivum L.). For this, different treatment biochar (BC), manure (OM), low mineral fertilizer (HL), high mineral fertilizer $(\mathrm{HF})$, and no fertilizer (FO) were used for the enzyme activities and bacterial community structure diversity tested. The result showed that organic amendment application increased total nitrogen, soil available phosphorus, and potassium compared to inorganic fertilizer and control, especially in the rhizosphere. Enzyme activities were generally higher in the rhizosphere than in the bulk soil and organic amendments increased activities of acid phosphatase (AcP), $\beta-1,4-N$-acetyl-glucosaminidase (NAG), and phenol oxydase (PhOx). Compared with soil and rhizosphere, bacterial diversity was lower in wheat roots and evenlower in the spikelet. From the bulk soil, rhizosphere to roots, the fertilization regimes maintained bacterial diversity, while organic amendment increased bacterial diversity in the spikelet. Fertilization regimes significantly influenced the relative abundances of 74 genera across 12 phyla in the four compartments. Interestingly, the relative abundance of Proteobacteria (Citrobacter, Pantoea, Pseudomonas, and unclassified Enterobacteriaceae) in the spikelet was decreased by increasing inorganic fertilizer and further by manure and biochar, whereas those of Actinobacteria (Microbacterium and an unclassified Microbacteriaceae) and Bacteroidetes (Hymenobacter and Chitinophagaceae) were increased. The results suggest that potential bacterial functions of both roots and above-ground parts of wheat would be changed by different organic amendment regimes (manure and biochar).
\end{abstract}

Keywords: fertilization; soil enzyme activities; bacterial communities; above-ground part; below-ground part; soil properties 


\section{Introduction}

Most of the biodiversities are found in the soil and they play an important role in the agroecosystems. These biodiversities provide ecosystem services beyond their normal functions which have considerable direct and indirect effects on the growth and quality of crops. In addition, they play an important role in crop protection and soil fertility [1]. In recent years, agroecosystem biodiversity and the activity of soil microbial communities have been considered as indicators of overall soil health and sustainability of soil productivity [2] by contributing to plant nutrition. However, the microbiota availability is sensitive to the environment and human management through agricultural or industrial chemicals usage [3], because they are the main causes of biodiversity loss with negative consequences on the environment [4]. In previous studies, fertilizer application was reported to have a significant effect on soil microbiota [5]. Tiemann et al. [6] and D'Acunto et al. [7] found that field fertilization experiment systems have a great influence on soil microbial diversity, which reflects changes and has been used as bio-indicators of soil quality [8]. To meet such challenges, the soil biology of agroecosystems is increasingly managed due to their contribution to nutrient cycling $[1,9]$ and better regulation of soil $\mathrm{C}$ accumulation $[10,11]$. Therefore, it is important to investigate the microbe in the agroecosystem.

Fertilization has been reported to be a very important strategy for managing crop yields as it improves soil fertility [12]. Previous studies have shown that inorganic and organic fertilization treatments have important effects on the structure, abundance, and activity of the soil microbial community directly by providing nutrients [13-19] and indirectly by modifying soil $\mathrm{pH}$ [15]. For instance, manure is the most commonly used organic fertilizer as it can increasethe richness and diversity of bacterial communities compared to the application of mineral fertilizers [20]. Nowadays, researchers are interested in the application of biochar which has a porous structure that increases moisture retention of soils [21]. Therefore, there is a great interest in the application of biochar as a soil amendment to improve $C$ sequestration [22,23] and soil organic matter [24]. In recent years, researchers have also reported biochar to enhance not only soil chemical properties but also increased bacterial richness and diversity of bacterial communities. Several studies have demonstrated the importance of manure and biochar amendments $[25,26]$. Both manure and the biochar are involved in modifying the amount and structural diversity of soil microbes and enhancing biochemical activities. However, few studies have compared these different forms of fertilizers and amendments on their effects on soil microbes.

A microbe is inhabited everywhere in the agroecosystem. In addition, soils are the friendliest microbial habitats on Earth [4]. The bulk soil microbiome is made up of microbial communities living mainly without direct interaction with the plant and provides carbon and nutrients [27]. In addition, a lot of research studies evoking the effect of fertilizers on the bacterial community structure in the bulk soil have been conducted $[2,28,29]$. Nowadays, many studies have also focused on the bacterial community structure in the rhizosphere $[19,30,31]$ perhaps due to the direct influence of the root system. The rhizosphere is considered a hot spot of microbial species [32], which participate in different nutrient transformations in the soil and determine their availability to plants [33]. Several studies have demonstrated the effect of $\mathrm{N}$-fertilization on microorganisms' community in the bulk soil and rhizosphere [19,34]. Furthermore, much has been learned about the interactions between soil microorganisms, inside and outside the root [35]. Chen et al. [36] observed the rhizosphere and wheat root's bacterial community compositions under different $\mathrm{N}$ fertilization levels [36]. However, in most experiments, measurements of soil microbiome and enzyme activity under varied soil amendments were not compartmentalized into the rhizosphere, bulk soil, and root-associated bacterial communities. Furthermore, there is not much information on the effects of fertilizer applications on the root of wheat microbiome responses and the above-ground parts of wheat. Therefore, there is a great interest to better understand the influence of various fertilizations on the diversity and community structure inside and outside the root.

Bacterial community structure and function are closely related [37]. This relationship generally results in an increase in plant production (i.e., function) and at the same time an increase in biodiversity [38]. In addition, communities differed in terms of specific functions, such as enzyme activities, but retained 
similar functions, such as biomass production and respiration [37]. Various microbial communities are responsible for specific functions and bacteria dominate in initial phases of decomposition of plant residues [16]. Several studies have revealed that fertilizer application was mainly characterized by the prevalence from the different bacteria phyla in the rhizosphere or bulk soil [39-42]. However, the influence of fertilization regimes on the microbial communities differed among fertilization forms [43] and soil types. These variations in the relative abundance implied that the effect of fertilizer may be correlated with the soil properties. In addition to microbial community structure, fertilizers are often applied to enhance enzyme activities [44,45]. Several studies have demonstrated that microbes, in a continuous process of digesting organic matter, improve soil structure $[27,46,47]$ as well as affect soil enzyme activities $[15,45,48]$. We hypothesized that biochar and manure applications promote soil enzyme activity and bacterial community diversity more than inorganic fertilizer in the below- and above-ground parts of wheat. Within this context, using phenotypic and sequencing approaches, the aims of this study were to (i) investigate the enzyme activities in soil and the bacterial communities diversity and structure in bulk soil, rhizosphere, roots, and spikelet, and (ii) assess the relationships between soil properties of the rhizosphere and the above- and below-ground wheat plant organs on the bacterial community under different fertilization regimes.

\section{Materials and Methods}

\subsection{Experimental Site and Design}

A field experiment was conducted in 2018 at Suzhou City in the Anhui Province, China, with its longitudes ranging from $116^{\circ} 58^{\prime} 2^{\prime \prime} \mathrm{E}$ to $116^{\circ} 58^{\prime} 56.09^{\prime \prime} \mathrm{E}$, and latitudes ranging from $33^{\circ} 38^{\prime} 41^{\prime \prime} \mathrm{N}$ to $33^{\circ} 38^{\prime} 13^{\prime \prime}$ N [49]. The field was under a winter wheat (Triticumaestivum L.) cultivar Zhoumai 22. Seeds of wheat were sown as seedlings following standard methods. The topsoil from the location has the following chemical properties: $\mathrm{pH}, 7.54$; soil:water ratio, $1: 2.5$; water content $24.78 \%$; total nitrogen (TN) $1.215 \mathrm{mg} \mathrm{g}^{-1}$; total carbon (TC) $9.028 \mathrm{mg} \mathrm{g}^{-1}$; carbon:nitrogen ratio $12: 1 ; \mathrm{NH}_{4}$ content $8.216 \mathrm{mg} \mathrm{kg}^{-1}$; $\mathrm{NO}_{3}$ content $24.04 \mathrm{mg} \mathrm{kg}^{-1}$; soil available phosphorus (AP) $9.25 \mathrm{mg} \mathrm{kg}^{-1}$; soil available potassium (AK) $162 \mathrm{mg} \mathrm{kg}^{-1}$. The experimental treatments consisted of two levels of inorganic fertilizer (low fertilizer and high fertilizer), two organic amendments (manure and biochar), and a control without fertilizer (FO). The five treatments were implemented in a randomized complete block design with four replications. Each plot $(7 \mathrm{~m} \times 6.6 \mathrm{~m})$ was separated from the adjacent plot by barriers of $1 \mathrm{~m}$ in size. Inorganic fertilizer treatments (NPK) were applied in the form of urea for N, calcium superphosphate for $\mathrm{P}_{2} \mathrm{O}_{5}$, and potassium chloride for $\mathrm{K}_{2} \mathrm{O}$.Manure was cow dung (dry weight) and its average nutrient contents were $169.73 \mathrm{mg} \mathrm{g}^{-1}$ of carbon, $30.84 \mathrm{mg} \mathrm{g}^{-1}$ of $\mathrm{N}$, and $5.52 \mathrm{of} \mathrm{C} / \mathrm{N}$; and biochar, with an average composition of $296.58 \mathrm{mg} \mathrm{g}^{-1}$ of carbon, $6.97 \mathrm{mg} \mathrm{g}^{-1}$ of $\mathrm{N}$, and $42.58 \mathrm{of} \mathrm{C} / \mathrm{N}$. The fertilization schedule for each treatment was as follows; $\mathrm{LF}, \mathrm{N}: \mathrm{P}_{2} \mathrm{O}: \mathrm{K}_{2} \mathrm{O}=150: 112: 75 \mathrm{~kg} \mathrm{ha}^{-1}$, high mineral fertilizer (HF), $\mathrm{N}: \mathrm{P}_{2} \mathrm{O}_{5}: \mathrm{K}_{2} \mathrm{O}=300: 225: 150 \mathrm{~kg} \mathrm{ha}^{-1}$, manure (OM), $4200 \mathrm{~kg} \mathrm{ha}^{-1}$, and biochar (BC), 10,500 kg ha-1. In this study, the rhizosphere is considered as the area of intense soil activity where roots grow. The bulk soil is outside the rhizosphere and it is not penetrated by plant roots.

\subsection{Soil Sampling and Analysis}

Topsoil samples were collected across the field at a depth of $0-20 \mathrm{~cm}$ before the treatments were established in March 2018 to evaluate initial soil characteristics. Soil $\mathrm{pH}$ was determined in a 1:2.5 soil-to-water mixture ratio and measured with digital Mettler Toledo meters ( $\mathrm{pH}$ meter). The soil's water content (moisture) was determined gravimetrically by weighing and drying in a hot air oven at $105^{\circ} \mathrm{C}$ for $24 \mathrm{~h}$, then reweighing [19]. Nitrate $\left(\mathrm{NO}_{3}{ }^{-}\right)$, ammonium $\left(\mathrm{NH}_{4}{ }^{+}\right)$, and available phosphorus (AP) concentrations were determined in the extract colorimetrically. The AP was determined by blue molybdenum based on the method developed by Olsen et al. [50] with $880 \mathrm{~nm}$ wavelength, while $\mathrm{NH}_{4}{ }^{+}$and $\mathrm{NO}_{3}{ }^{-}$absorbance values were measured at a wavelength of 625 and $275 \mathrm{~nm}$, respectively. 
Available potassium (AK) was determined by the flame photometric method. Total nitrogen (TN) was determined by Kjeldahl distillation.

Prior to wheat harvest, bulk and rhizosphere soil samples were collected in July 2018. Three soil cores were collected and pooled together as a composite sample from the four replicates for each treatment plot avoiding border effects. The cores were collected using an Oakfield hand probe (bulk soils) and shovel (rhizosphere). The operation was repeated at the level of each treatment from one dimension to another while leaving $1 \mathrm{~m}$ interval between the plots and alleys. For rhizosphere soil, plants with their roots were uprooted. Upon the arrival of the samples at the laboratory, the sticky soil was shaken and separated from the roots. The composite samples were stored at $-20{ }^{\circ} \mathrm{C}$ after collection until analysis. One portion of the composite soil was stored for molecular analysis and soil enzyme activities, while another portion was stored at $4{ }^{\circ} \mathrm{C}$, air-dried, and used for chemical nutrients analysis, except for ammonium $\left(\mathrm{NH}^{+}\right)$and nitrate $\left(\mathrm{NO}^{-}\right)$soils which were stored in $-20^{\circ} \mathrm{C}$.

\subsection{Soil Enzymes Assay}

Activities of acid phosphatase (AP), $\beta$-1,4-Nacetylglucosaminidase (NAG), $\beta$-1,4-glucosidase $(\beta G)$, and phenol oxydase (PhOx) enzymes were quantified in all the soil sample solutions in both rhizosphere and bulk soils. The activities of these soil enzymes were measured following the methods described in Saiya-Cork et al. [51] for fluorimetric enzymes and [52] for the spectrophotometric enzyme (PhOx). Microplate technology was used because it allows multiple enzymes to be assayed on a single plate [53]. The enzymatic microplate assay using fluorescence is a test applicable to any enzyme for which there is a fluorescently labeled substrate 4-methylumbelliferyl (MUB) after hydrolysis [51,53,54]. Enzyme activities such as AP, NAG, and BG were measured by fluorimetry according to Marx et al. [54] and Saiya-Cork et al. [51]. The activities of phenol oxydase were measured spectrophotometrically according to the method described by DeForest [52]. Since PhOx is sensitive to light and temperature [52,55], the microplates were covered and incubated for $4 \mathrm{~h}$ at $25^{\circ} \mathrm{C}$ in the dark [56,57]. In the analysis, four replicate-wells for each blank, a negative control, and a quench standard were used. The plate was read at an appropriate wavelength using the Gen5 software [58]; fluorescence plates for a black 96-well microplate and spectrophotometer plates for a clear 96-well microplate (phenol oxidase plates) were read using L-3, 4-dihydroxyphenylalanine (L-DOPA) as the substrate. The activity was quantified by measuring absorbance at $365 \mathrm{~nm}$ excitation and $450 \mathrm{~nm}$ emission filters using a microplate spectrophotometer and expressed in units of nanomole per gram of soil per hour $\left(\mathrm{nmol} \mathrm{h}^{-1} \mathrm{~g}^{-1}\right)$ [59].

\subsection{Illumina High-Throughput Sequencing and Data Processing}

\subsubsection{DNA Extraction}

The FastDNA SPIN Kit for Soil (MP Biomedicals, Santa Ana, CA, USA) was used to extract DNA from $0.5 \mathrm{~g}$ of each sample $[43,60]$ according to the manufacturer's protocol and quantified spectrophotometrically (Nanodrop ND-2000, Thermo Fisher Scientific, Waltham, MA, USA). Samples extracted were processed using a FastPrep24 instrument (MP Biomedicals, Solon, OH, USA) [61]. For root communities, a section of crushed root tissue (with liquid nitrogen) was used for DNA extraction. The DNA sample from the panicle represents the microbial communities of the ground dried wheat head (both pod and grain). At the end of the season (July 2018), wheat spikelets were harvested, dried, and threshed for microbial community assessment. The DNA quality was checked using $1.0 \%$ agarose gels. The obtained DNA was then stored in a $-20{ }^{\circ} \mathrm{C}$ freezer until molecular analysis.

\subsubsection{Polymerase Chain Reaction (PCR) Amplification}

Preliminary tests (series of dilutions) made it possible to know whether or not the DNA had to be diluted before PCR amplification so that the extracted DNAs were diluted to a concentration of about $0.1 \mathrm{ng} / \mu \mathrm{L}$ before PCR amplification [62]. The universal primer $16 \mathrm{~S}$ rRNA gene was used for prokaryotic 
microbes in the PCR to determine the diversity of microbial communities in bulk soils, rhizosphere, roots, and wheat spikelets. Illumina HiSeq sequencing of $16 \mathrm{~S}$ rRNA gene amplicons allowed to analyze the compositions of bacterial communities. The Microbial amplicon library V4 region of 16S rRNA genes was amplified for each sample with primer set 515F (5'-GTGCCAGCMGCCGCGGTAA- $3^{\prime}$ ) and 806R (5'-GGACTACHVGGGTWTCTAAT-3') with a 12-bp barcode attached to 806R. The PCR was carried out with $50 \mu \mathrm{L}$ as the total volume of the reaction mixture. The effective mixture was $\mathrm{ddH}_{2} \mathrm{O}$ $(35.5 \mu \mathrm{L}), 10 \times$ Buffer $(5 \mu \mathrm{L})$, dNTPs $(4 \mu \mathrm{L})$, Forward Primer 515F $(1 \mu \mathrm{L})$, Reverse Primer 806R $(1 \mu \mathrm{L})$, Taq Pol $(0.5 \mu \mathrm{L})$, and DNA Template $(2 \mu \mathrm{L})$. The thermal conditions for the bacterial $16 \mathrm{~S}$ rRNA gene were 5 min at $94{ }^{\circ} \mathrm{C}$ and 35 cycles: 45 s at $94^{\circ} \mathrm{C}, 35$ s at $55^{\circ} \mathrm{C}, 45$ s at $72{ }^{\circ} \mathrm{C}$, with a final elongation at $72^{\circ} \mathrm{C}$ for $10 \mathrm{~min}$. A quantitative assay of total dsDNA was performed using the Varioskan and PicoGreen dsDNA Quantitation Kit then the TIANgel Midi DNA Purification Kit (www.tiangen.com/en), and the purified DNA was then used for sequencing. The amplicons were grouped and pooled at equimolar concentration sequenced on an Illumina HiSeq platform according to standard protocols.

\subsubsection{Bioinformatics Analysis}

Sequences were processed as previously reported [63]. Briefly, sequences with quality scores greater than 25 and without mismatches between the barcode and primer were processed further. The sequences were trimmed to $250 \mathrm{bp}$ before clustering with UPARSE at a 97\% similarity level [64]. Chimeras in the sequences were filtered with UCHIME [65]. The sequence analysis was performed using the USEARCH package [66]. Representative sequences were classified on a RDP classifier [67]. An OTU table was rarefied to 10,000sequences per sample for the $16 \mathrm{~S}$ rRNA gene. The sequences were deposited in the National Center for Biotechnology Information (NCBI) Sequence Read Archive (SRA) under accession number SRP074820. Shannon's diversity index was calculated with the diversity function in the vegan package.

\subsection{Statistical Analyses}

Statistical analyses were carried out by using a one-way analysis of variance (ANOVA) procedure in the SPSS software (IBM SPSS Statistics v22) to detect differences in soil parameters, soil enzyme activities, the bacterial relative abundance, and Shannon indexes. Differences between treatment means were compared using Fisher's LSD method at the 5\% probability level. Canonical correlations analysis (CCA) was performed with the cca function in the vegan package.

\section{Results}

\subsection{Soil Properties in the Bulk and Rhizosphere Soil}

The interplay of soil amendment type in the bulk and rhizosphere soil was observed on the concentrations of soil properties (Figure 1). There was a significant difference $(p<0.05)$ between the treatments in the bulk soil. The application of OM gave the highest percentage of water which was statistically at par with FO, FL, and BC and significantly different from FH. However, in the rhizosphere, no significant difference $(p>0.05)$ was observed between the treatments. The FH treatment recorded the lowest $\mathrm{pH}$ in the bulk soil and had the highest $\mathrm{NH}_{4}$ concentration. Similarly, in the rhizosphere, the $\mathrm{FH}$ treatment recorded the lowest $\mathrm{pH}$ but was statistically similar to FL. The application of biochar resulted in the lowest concentration of $\mathrm{NH}_{4}$ in the bulk soil and the highest concentration in the rhizosphere. There were no significant differences $(p>0.05)$ between the treatments for available $\mathrm{P}, \mathrm{NO}_{3}$, and total $\mathrm{N}$ in the bulk soil. In the rhizosphere, the $\mathrm{OM}$ treatment recorded the highest available P which was statistically at par with BC and FL. The BC treatment had the highest available $\mathrm{K}$ followed by $\mathrm{OM}, \mathrm{FH}$, and FL which had no significant differences, but they all differed from the control (FO). The FH treatment had the highest $\mathrm{NO}_{3}$ concentration which was statistically similar to FL. No significant difference was observed between $\mathrm{OM}$ and $\mathrm{BC}$ but all the amendments were significantly different from the control (FO) for $\mathrm{NO}_{3}$ concentration. 
A

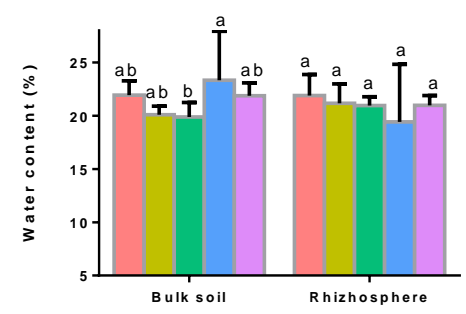

D

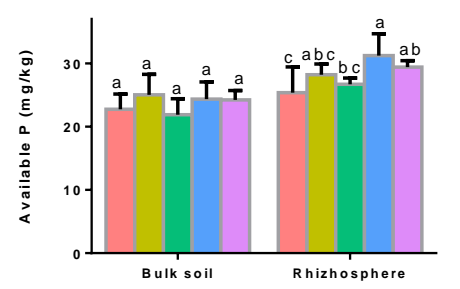

B

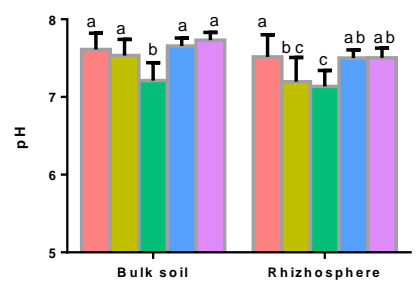

E

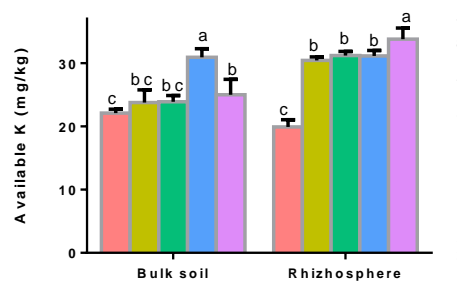

G

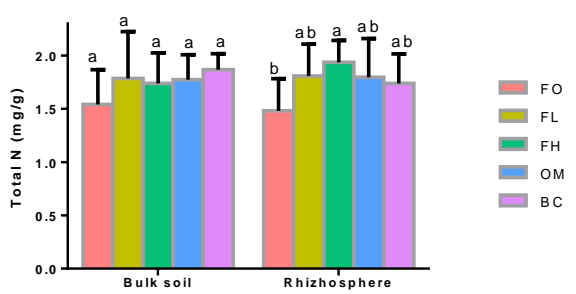

C

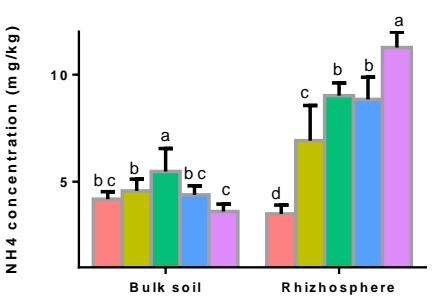

$\mathbf{F}$

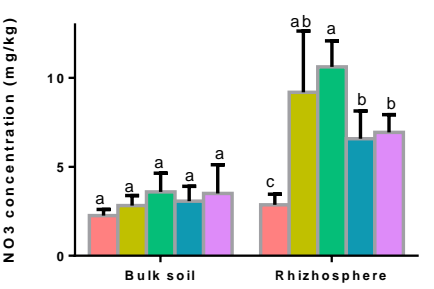

Figure 1. Effect of the treatments on selected soil properties before wheat harvest. Soil properties measured include (A) water content (\%); (B) $\mathrm{pH} ;(\mathbf{C})$ ammonium $\left(\mathrm{NH}_{4}{ }^{+}-\mathrm{N}\right)$ concentration $\left(\mathrm{mg} \mathrm{kg}^{-1}\right)$; (D) nitrate-nitrogen $\left(\mathrm{NO}_{3}{ }^{-}-\mathrm{N}\right)$ concentration $\left(\mathrm{mg} \mathrm{kg}^{-1}\right)$; (E) available phosphorus; (F) available potassium; and (G) total nitrogen $\left(\mathrm{mg} \mathrm{g}^{-1}\right.$ ). FO: no fertilizer, control; LF: low fertilizer; HF: high fertilizer, OM: manure; and BC: biochar. Values are the means of the eight replicates of each treatment. The different alphabet letters indicate that there are significant differences (ANOVA, LSD test, $p<0.05$ ) among fertilizer treatments. The error vertical bars represent standard error bars.

\subsection{Soil Enzyme Activities}

Extracellular enzymes (AcP, acid phosphatase; NAG, $\beta-1,4-N$-acetyl-glucosaminidase; PhOx, phenol oxidase and BG, $\beta$-1,4-glucosidase) activities were quantified in both rhizosphere and bulk soils according to soil amendments (Figure 2). The result shows that enzyme activities are higher in the rhizosphere than in the bulk soil under varied soil amendment conditions. Significant differences $(p<0.05)$ were observed between the treatments for the soil enzyme activities. The organic amendment increases the activity of AcP in the rhizosphere while the inorganic fertilizer application has no detectable effect on AcP activity. The FH treatment reduces the activity of AcP enzyme in the bulk soil which was statistically similar to FL and OM. The activity of the NAG enzyme increases significantly in the bulk soil under the BC amendment while OM favors NAG activity in the rhizosphere compared to the other amendment methods and control. The FH treatment reduces the activity of BG in the rhizosphere. Manure and biochar application increased most enzyme activities compared to chemical fertilizer treatments (LF and HF), except for NAG, in both rhizosphere and bulk soils. 


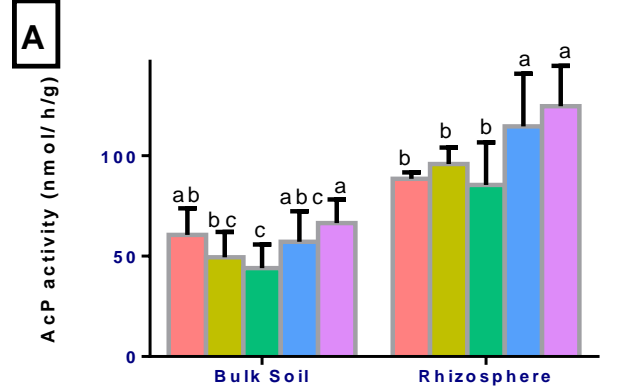

C

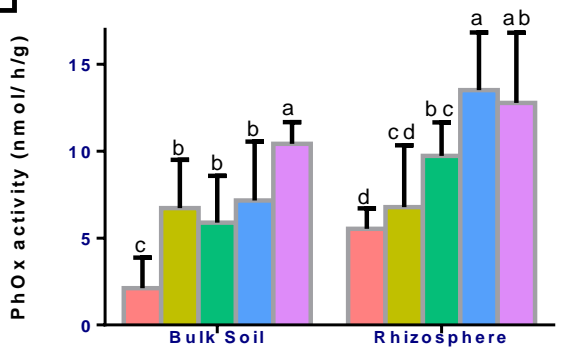

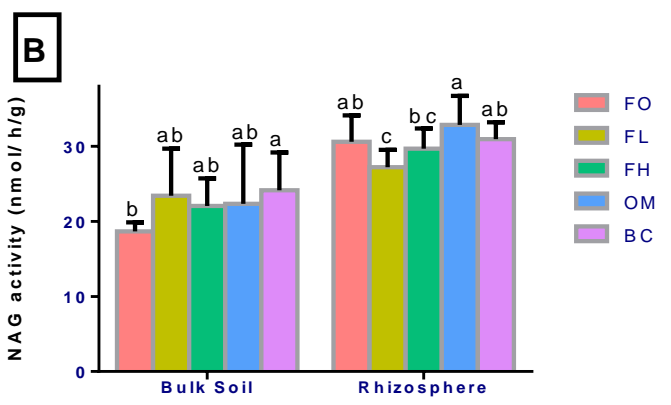
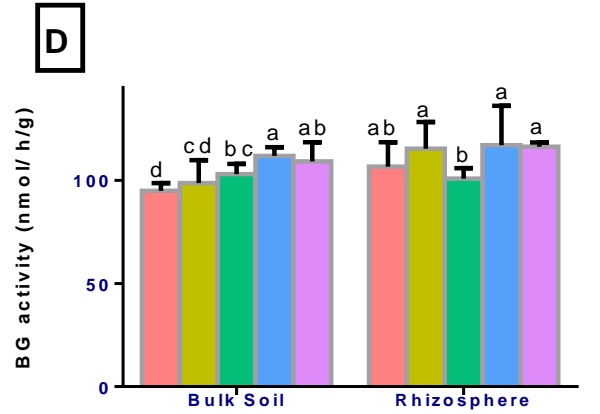

Figure 2. Soil enzyme activities across chemical fertilizer, manure, and biochar treatments in rhizosphere and bulk soils. (A) AcP, acid phosphatase; (B) NAG, $\beta-1,4-N$-acetyl-glucosaminidase; (C) PhOx, phenol oxidase; and (D) BG, $\beta$-1,4-glucosidase. Units for all enzyme activities are nmol activity $\mathrm{h}^{-1} \mathrm{~g}^{-1}$ soil. FO: no fertilizer, control; LF: low fertilizer; HF: high fertilizer, OM: manure; and BC: biochar. Values are the means of the eight replicates of each treatment. The different alphabet letters indicate that there are significant differences (ANOVA, LSD test, $p<0.05$ ) among fertilizer treatments. The error vertical bars represent standard error bars.

\subsection{BacterialCommunity}

\subsubsection{Alpha Diversity (Shannon Index)}

The microbial diversity of OTUs in several compartments (bulk soil, rhizosphere, root, and panicle of wheat) was measured using Shannon's diversity index $\left(\mathrm{H}^{\prime}\right)$ according to different types of treatments (Figure 3). The Shannon diversity index $\left(\mathrm{H}^{\prime}\right)$ of the bacterial communities in the rhizosphere is greater than those in bulk soil followed by root and spikelet in that order (Figure 3). Furthermore, higher bacterial richness in the rhizosphere is not sensitive $(p>0.05)$ to the soil amendment type. In the bulk soil, FH treatment had the highest index which was significantly different from the OM with the lowest index but statistically onpar with the other treatments. In the roots, the control treatment had the highest index which was statistically similar to the inorganic amendments but differed significantly from the organic amendments. The OM treatment had the highest index in the spikelet which was significantly different from the inorganic fertilizer amendments and control but statistically similar to BC.

\subsubsection{Bacterial Community Structures}

The bacterial communities at the phylum level collected from Illumina sequencing indicated only phyla with relative abundance greater than $1 \%$ in the four compartments among the different treatments (Figure 4). The relative abundance of other phyla (unclassified) was therefore at less than $0.5 \%$ of the total composition in the libraries. The dominant phyla of bacteria were obviously different between soil and the above- and below-plant organs. In the plant parts (root and spikelet), the predominant bacteria were Proteobacteria followed by Bacteroidetes and Actinobacteria. In the rhizosphere and bulk soil, the predominant bacteria were Proteobacteria followed by Acidobacteria, Thaumarchaeota, Actinobacteria, and Bacteroidetes. Other important phyla that were found: Chloroflexi and Verrucomicrobia (bulk soil, rhizosphere, and root) and Firmicutes (spikelet). Proteobacteria was the most dominant phyla in spikelet, root, and rhizosphere of wheat accounting for $>75 \%,>65 \%$, and $>25 \%$, respectively. Acidobacteria were 
the most dominant phyla $(>40 \%)$ in the bulk soils, while they represented $>20 \%$ in the rhizosphere and less than $10 \%$ in root and spikelet. Bacteriodetes are found in all compartments but are higher in the roots and rhizosphere, while Actinobacteria phyla are higher in the soil components (bulk soil and rhizosphere). Thaumachaeota and Chloroflexi also account for a meaningful proportion of the bacterial community in the bulk soil and rhizosphere but almost absent in the spikelet and root compartments. However, both root and spikelet phyla were very similar. Moreover, the rhizosphere gets closer to them than bulk soil. There may be, therefore, a link connecting different bacterial communities of the rhizosphere soil and the above- and below-ground organs of wheat plant communities.

The relative abundance of Proteobacteria decreases from the control treatment followed by FL, FH, $\mathrm{OM}$, and $\mathrm{BC}$ and vice versa for Bacteroidetes and Actinobacteria in the spikelet. In the root, the relative abundance of Proteobacteria was higher in the organic amendment treatments than in the inorganic amendment treatments and control. No discernible pattern was observed between the treatments in the relative abundance of the bacteria in the rhizosphere and bulk soil.

\subsubsection{Genus Differed in Different Treatments}

The detail of the abundances of the bacterial community profiles at the genus level based on the $16 \mathrm{~S}$ rRNA gene is presented in a clustered heat map plot (Figure 5). The result shows that the abundance of the various bacterial phyla differs between compartments. The similarity of abundance was highest among the two soil compartments (bulk and rhizosphere) while the variation was highest between soil and spikelet. Pseudomonas, Pantoea, and Citrobacter are more abundant in the plant organs (spikelet and roots) than in the soil compartments, while Nitrosospheara, Gp4, and Gp6 are more abundant in the soil than in the plant organs. Flavobacterium, Rhizobium, and Neorhizobium are more abundant in the roots than in other compartments from the heat map (Figure 5).

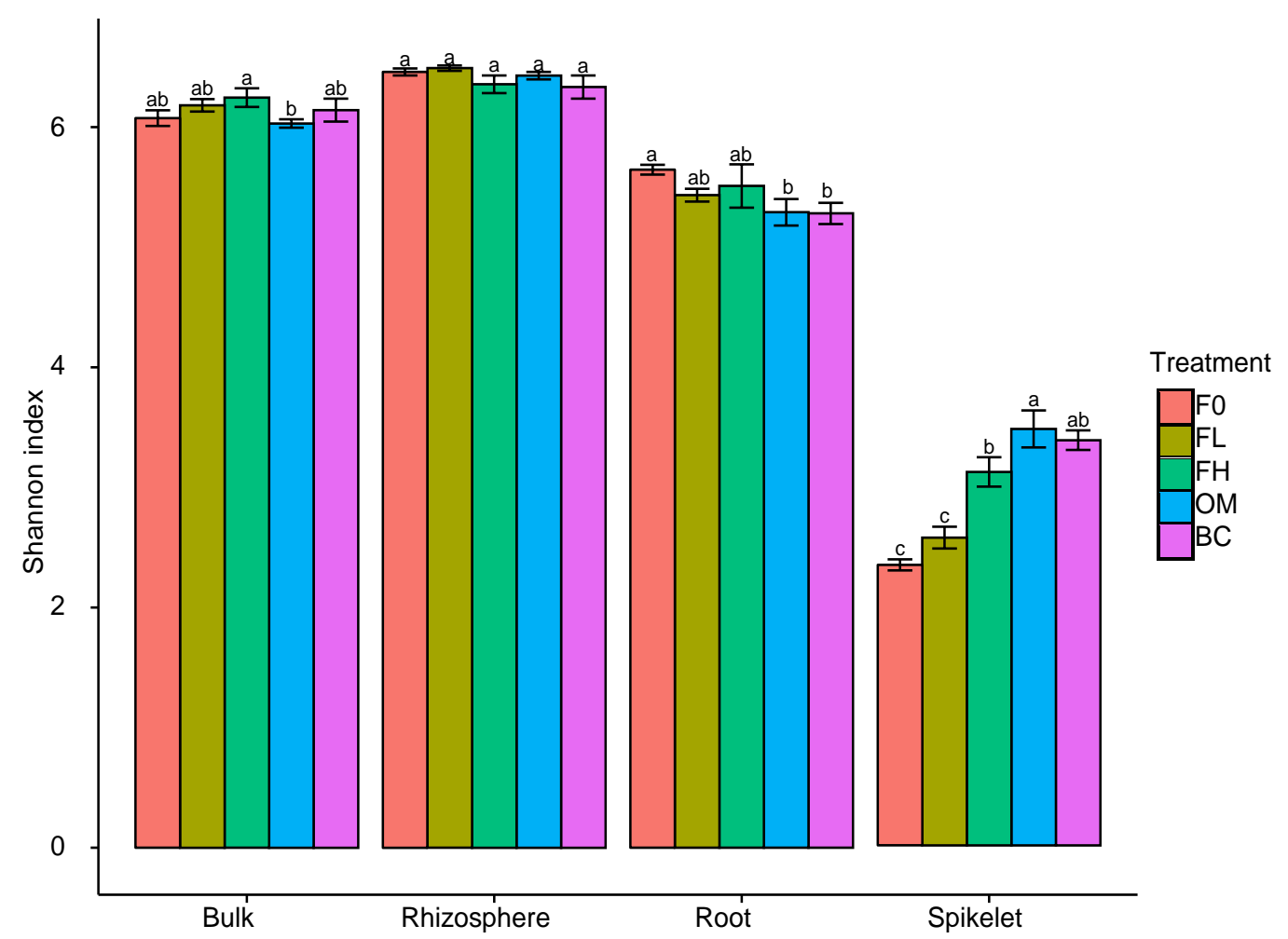

Figure 3. Shannon diversity index $\left(\mathrm{H}^{\prime}\right)$ measuring bacterial diversity for different compartments (bulk soil, rhizosphere, root, and spikelet of wheat) at different treatments (chemical fertilizer, manure, and biochar). The same letters above the bars are not significantly different among treatments (ANOVA, LSD test, $p<0.05)$. FO: no fertilizer, control; LF: low fertilizer; FH: high fertilizer; OM: manure; and BC: biochar. 


\subsection{Correlations Analysis between Soil Properties and Bacterial Community Structure}

The permutation test for the redundancy analysis (RDA) under the reduced model showed a correlation between soil properties and the bacterial community structure. According to the RDA that was used, the selected soil properties affected the composition of the bacterial community in bulk soil in the following descending order: $\mathrm{pH}>\mathrm{NH}_{4}{ }^{+}>\mathrm{NO}_{3}{ }^{-}>$water content $>\mathrm{TN}>\mathrm{AK}>\mathrm{AP}$ (Table 1). The RDA showed that the $\mathrm{pH}(p=0.04, \mathrm{r}=1.4796)$ was the major factor affecting the variability in the bacterial community structure in the bulk soil (Table 1), while the selected soil properties affected the composition of the bacterial community in the rhizosphere in the following order: $\mathrm{NH}_{4}{ }^{+}$ $>$ water content $>\mathrm{NO}_{3}{ }^{-}>\mathrm{pH}>\mathrm{AP}>\mathrm{TN}>\mathrm{AK}$ (Table 2). The RDA showed that $\mathrm{NH}_{4}{ }^{+}(p=0.005$, $r=2.1899$ ) was the major factor affecting the variation in the bacterial community structure in the rhizosphere (Table 2).Canonical correspondence analysis (CCA) based on the specific relationships and the bacterial community structure showed that the soil properties differed significantly among the different treatments (Figure 6). In the bulk soil, the bacterial community composition of $\mathrm{BC}$ treatments was positively affected by the $\mathrm{pH}, \mathrm{TN}, \mathrm{AK}, \mathrm{NO}_{3}, \mathrm{AP}$, and $\mathrm{NH}_{4}$, while the community composition of $\mathrm{FO}, \mathrm{FL}, \mathrm{FH}$, and $\mathrm{OM}$ was positively influenced by $\mathrm{NH}_{4}, \mathrm{AP}$, and $\mathrm{H}_{2} \mathrm{O}$ (Figure $6 \mathrm{~A}$ ). In the rhizosphere, $\mathrm{pH}, \mathrm{TN}, \mathrm{AK}, \mathrm{NO}_{3}, \mathrm{AP}$, and $\mathrm{NH}_{4}$ have a positive influence on the bacterial community composition of $\mathrm{BC}$ treatments, while the $\mathrm{FO}, \mathrm{FL}, \mathrm{FH}$, and $\mathrm{OM}$ treatments in the bacterial community composition were positively influenced by $\mathrm{H}_{2} \mathrm{O}$ (Figure 6B).

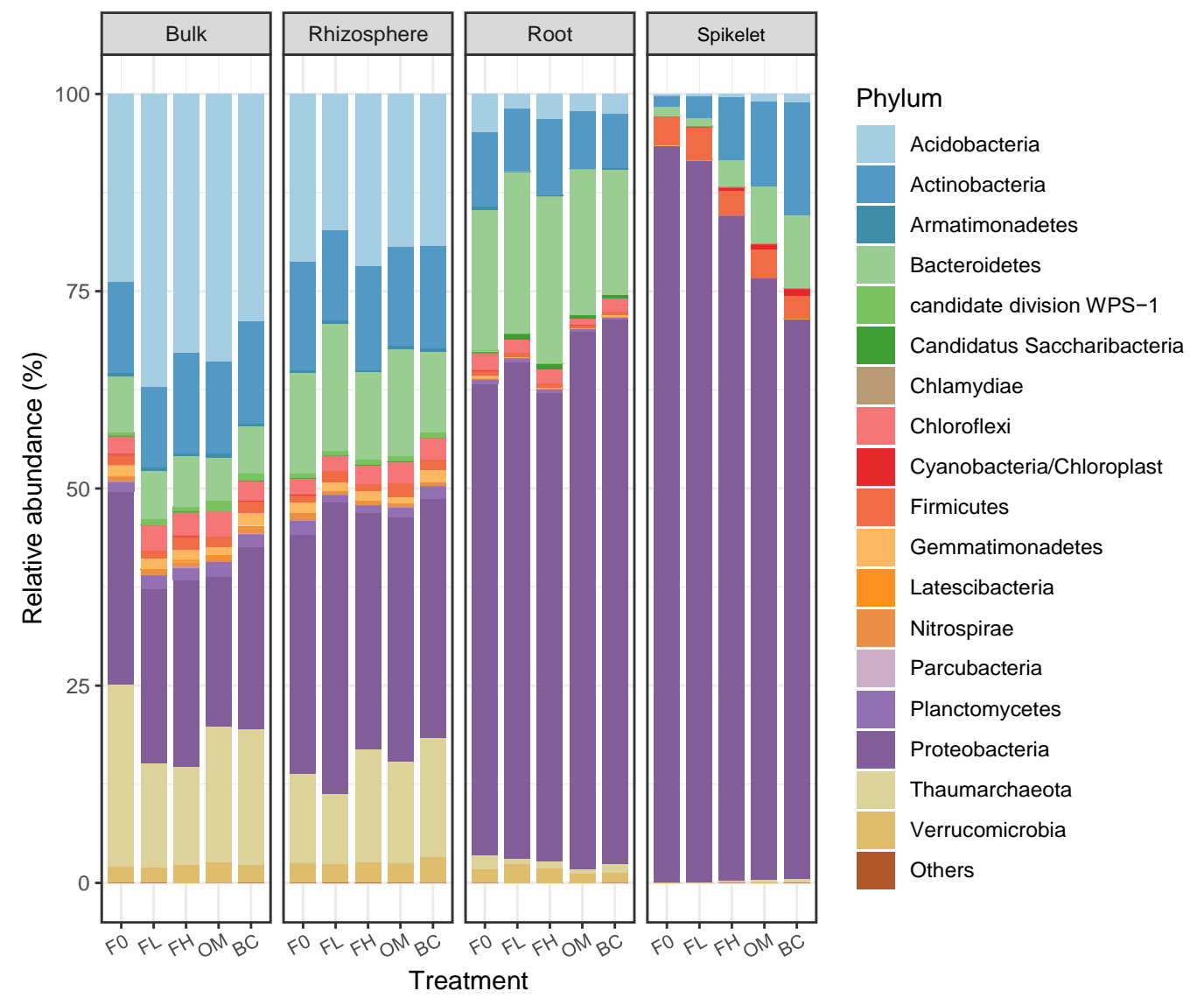

Figure 4. Compositions of soil bacterial community structure at the phylum in bulk soils, rhizosphere, root, and spikelet of wheat. FO: no fertilizer, control; LF: low fertilizer; FH: high fertilizer; OM: manure; and BC: biochar. The bacterial communities at the phylum level collected from Illumina sequencing indicated only phyla with relative abundance greater than $1 \%$. The relative abundance of other phyla (considered unclassified) was therefore at less than $1 \%$ of the total composition in the libraries. 


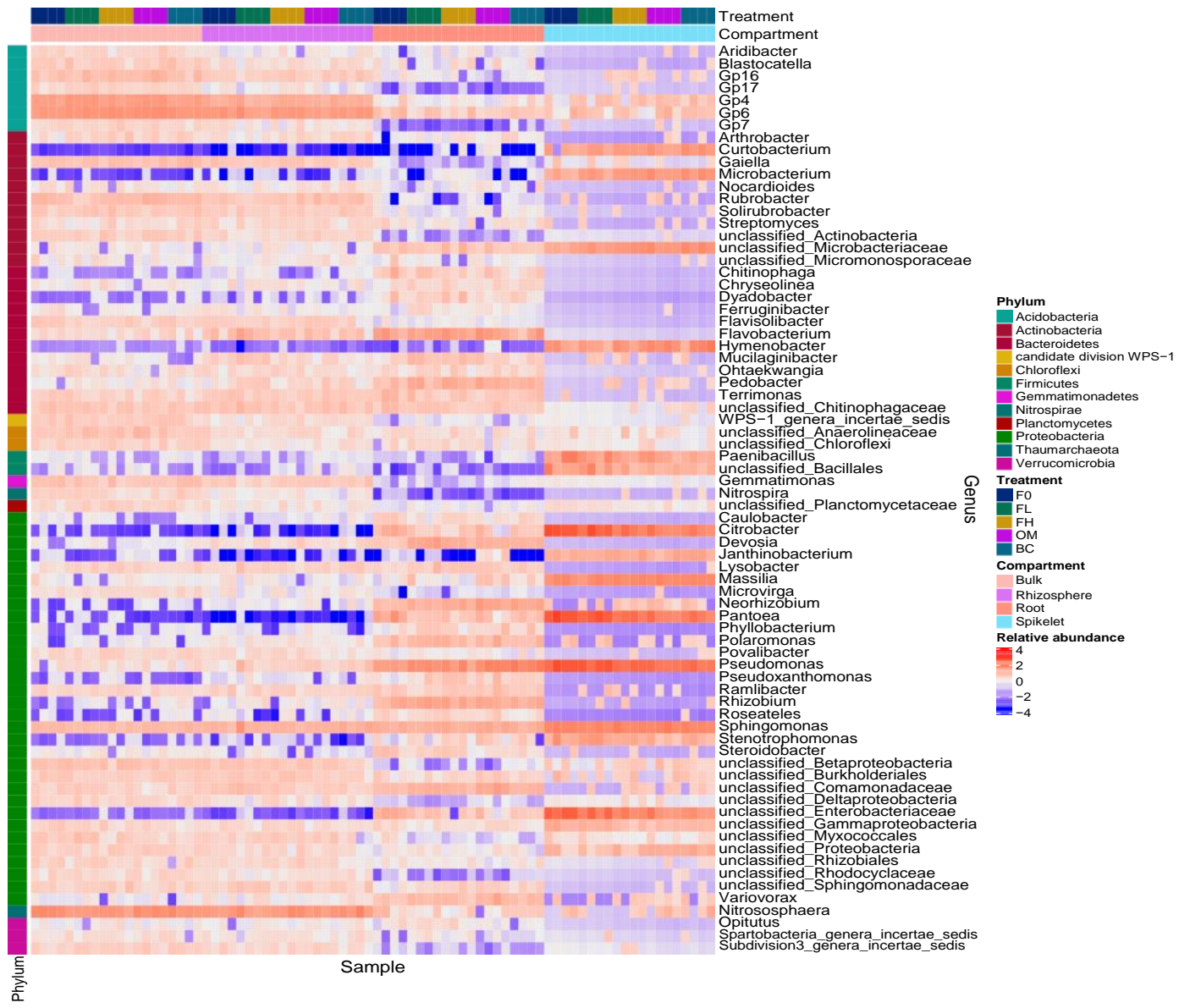

Figure 5. Heat map of the bacterial community showing the profiles-clustered results from plot abundances of the 16S rRNA gene at genus-level in bulk soils, rhizosphere, root, and spikelet of wheat.FO: no fertilizer, control; LF: low fertilizer; FH: high fertilizer; OM: manure; and BC: biochar.

Table 1. The relationship between the soil parameters and the bacterial community structure in the bulk soil.

\begin{tabular}{ccc}
\hline Soil Properties & \multicolumn{1}{c}{$r$} & $p$ \\
\hline $\mathrm{H}_{2} \mathrm{O}$ & 1.0043 & 0.426 \\
$\mathrm{pH}$ & 1.4796 & $0.040^{*}$ \\
$\mathrm{NH}_{4}^{+}$ & 1.3446 & 0.099 \\
$\mathrm{NO}_{3}{ }^{-}$ & 1.1714 & 0.225 \\
$\mathrm{AP}$ & 0.8341 & 0.742 \\
& 0.8708 & 0.660 \\
$\mathrm{TN}$ & 0.9062 & 0.5 \\
\hline
\end{tabular}

${ }^{*}=p<0.05 .{ }^{a}$ Soil parameter codes: $\mathrm{H}_{2} \mathrm{O}$ : water content; soil $\mathrm{pH} ; \mathrm{NH}_{4}{ }^{+}$: ammonium concentration; $\mathrm{NO}_{3}{ }^{-}$: nitrate nitrogen concentration; AP: available phosphorus; AK: available potassium; and TN: total nitrogen. 
Table 2. The relationship between the soil parameters and the bacterial community structure in the rhizosphere.

\begin{tabular}{|c|c|c|}
\hline Soil Properties $^{a}$ & $r$ & $p$ \\
\hline $\mathrm{H}_{2} \mathrm{O}$ & 1.5873 & 0.094 \\
\hline $\mathrm{pH}$ & 1.2963 & 0.147 \\
\hline $\mathrm{NH}_{4}^{+}$ & 2.1899 & $0.005^{* *}$ \\
\hline $\mathrm{NO}_{3}^{-}$ & 1.4649 & 0.069 \\
\hline $\mathrm{AP}$ & 1.2421 & 0.18 \\
\hline AK & 0.8398 & 0.66 \\
\hline $\mathrm{TN}$ & 0.8483 & 0.677 \\
\hline
\end{tabular}

${ }^{* *}=p<0.01$. ${ }^{a}$ Soil parameter codes: $\mathrm{H}_{2} \mathrm{O}$ : water content; soil $\mathrm{pH} ; \mathrm{NH}_{4}{ }^{+}$: ammonium concentration; $\mathrm{NO}_{3}{ }^{-}$: nitrate nitrogen concentration; AP: available phosphorus; AK: available potassium; and TN: total nitrogen.
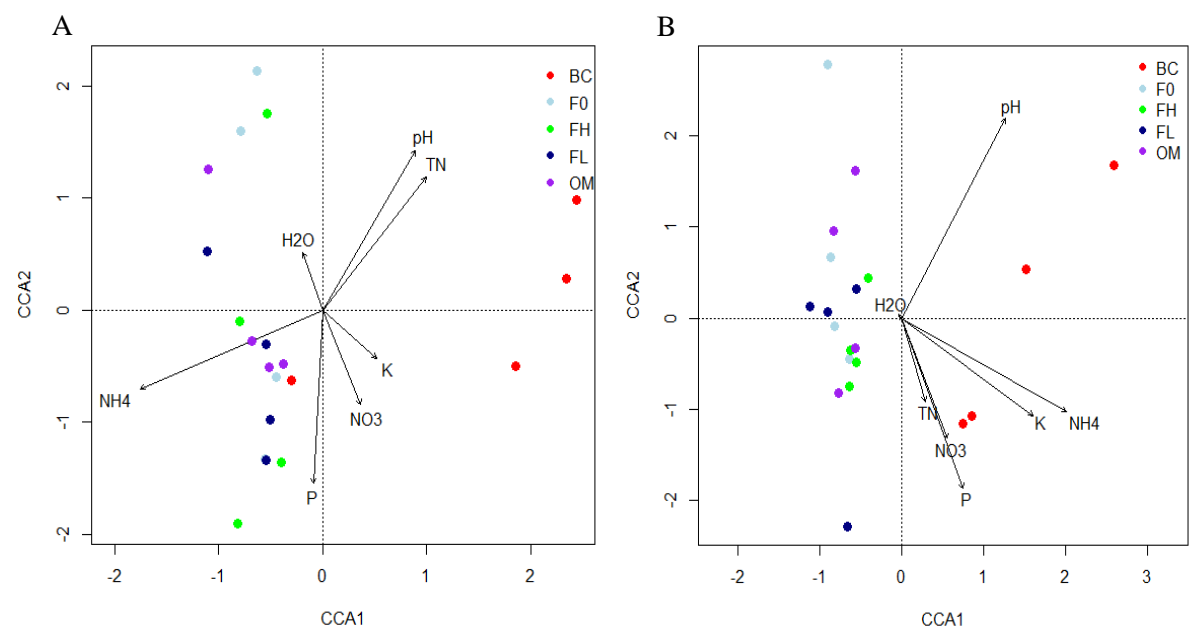

Figure 6. Canonical correspondence analysis (CCA) to show the correlation between the bacterial community structure and soil properties. (A) Bulk soil and (B) rhizosphere. Measured soil property factors include $\mathrm{pH}$, water content $(\%)$, nitrate $\left(\mathrm{NO}_{3}{ }^{-}\right)$, ammonium $\left(\mathrm{NH}_{4}{ }^{+}\right)$concentration $\left(\mathrm{mg} \mathrm{kg}^{-1}\right)$, total nitrogen $\left(\mathrm{mg} \mathrm{g}^{-1}\right)$, available phosphorus $\left(\mathrm{mg} \mathrm{kg}^{-1}\right)$, and available potassium $\left(\mathrm{mg} \mathrm{kg}^{-1}\right)$. Treatment: FO: no fertilizer, control; FL: low fertilizer; FH: high fertilizer; OM: manure; and BC: biochar.

\section{Discussion}

\subsection{Effect of Fertilization on Soil Properties}

According to literature, different sources of nutrients (organic and inorganic) of soil may influence soil properties. However, the overuse of chemical fertilizers can lead to nitrogen leaching, soil acidification, reduction of soil organic matter, and loss of soil carbon [68]. Here we have hypothesized that the likely effects of organic manure and biochar can increase soil properties, especially in the rooting zone. An increase in the water retention capacity of soil after fertilizer application is widely reported in scientific literature $[25,26]$. From the present study, it was observed that the water content of the different treatments responds differently in the bulk soil and rhizosphere. The different amendments did not affect the water content of the rhizosphere and a slight response was observed in the bulk soil. Bulk soil has a greater capacity for moisture retention and soil amended with $\mathrm{OM}$ has the highest water content. Plant roots directly take up more water for themselves and thismay explain why the rhizosphere has become much drier than the bulk soil [69]. However, Carminati et al. [70] reported that the water content in the rhizosphere is higher than in the bulk soil which he attributed to exudates released by plant roots. Therefore, the type of crop grown can influence the water content either in the bulk soil or rhizosphere. Fertilizer regimes lower soil $\mathrm{pH}$ towards neutral, which promotes the assimilability of soil nutrients. In this study, chemical fertilizers lower $\mathrm{pH}$ more than the organic amendments (OM and BC). It has been reported that when nutrient availability and absorption are optimal in soil, all soil 
amendments lower the $\mathrm{pH}$ [71]. The CCA results showed that the bacterial community was affected by fertilizer regimes. The communities are strongly correlated with soil $\mathrm{pH}$ and $\mathrm{NH}_{4}{ }^{+}$, in the bulk soil and rhizosphere, respectively, which is in accordance with previous studies [44]. These results illustrate that $\mathrm{pH}$ is the best predictor of bacterial community composition and diversity [72]. Bacterial communities were also the key determinant factors affecting soil enzyme activities.

\subsection{Effect of Fertilization on Soil Enzyme Activities}

Enzymatic activity in soil is largely related to the microorganisms [73], available nutrients [74], and root exudates [75]. Changes in the rhizosphere were distinctly different from those in bulk soil in most enzyme activities. In the present study, we measured the activities of four different enzymes under the different amendment treatments. We observed changes in the enzyme activities in response to fertilizer application regimes. The activities of all the enzymes were significantly higher in the rhizospheres than in the bulk soil except the activity of BG, justifying better soil health in the rooting zone [29]. Similar greater activities of enzymes in the rhizosphere than in the bulk soil have been reported [76-78]. Inorganic fertilizer application has no detectable influence on enzyme activities except FH treatment that showed significantly higher PhOx activity in rhizosphere compared to the control. However, Elsoury et al. [79] reported significant differences in the activity levels of enzymes with fertilization treatments. In agreement with the findings of the present study, Wang et al. [2] reported that activities of the NAG were not influenced by fertilization and with a cover crop [80]. Hence, the amended wheat rhizosphere has a great influence on soil enzyme activities, which confirms the conclusions of Suleiman et al. [33]. In addition, manure and biochar applications significantly increased enzyme activities in both soil compartments more than inorganic fertilizer application [76]. This implies that organic soil amendments are superior in the enhancement of enzyme activities but the degree of change was more pronounced in the activity of acid phosphatase and phenol oxidase. Zhang et al. [81] reported that manure application was of paramount importance to improve soil enzyme activities. Studies have reported $\beta$-glucosidase activity as an indicator of soil quality $[82,83]$ having the ability to stabilize soil organic matter [84]. Biochar application was reported to significantly influence enzyme activities in soils [45]. They further reported correlations in enzyme activity with soil properties, including water content, $\mathrm{NH}_{4}{ }^{+}$, available $\mathrm{P}$, available $\mathrm{K}$, total $\mathrm{N}$, and $\mathrm{NO}_{3}{ }^{-}$.

\subsection{Effects of Fertilization on Soil Bacterial Diversity and Community Composition}

As soil fertilization plays an important role in the bacterial community balance, we further elucidate the bacterial community diversity and structure of soil compartments and those of wheat plant organs, which are known to influence the plant uptake absorption of available nutrients [85]. Soil bacterial community composition significantly influenced the relative abundances of 74 genera across 12 phyla in the four compartments. The bacterial community differed across all compartments, and the higher abundances were all dominated by Proteobacteria, Acidobacteria, Bacteroidetes, Thaumachaeota, and Actinobacteria aton the phylum level. This finding is in agreement with previous studies that revealed a comparable abundance of these phyla of soil bacteria in bulk and rhizosphere soils [15,42,78]. The use of fertilizer continuously increased in the relative abundance of Proteobacteria and decreased the abundance of Acidobacteria and Thaumarchaeota from bulk soil, rhizosphere, and roots to spikelet. Long-term farming system practices on agricultural soil showed similar results $[78,86]$. The fertilization regimes gradually increased the bacterial diversity in the spikelet, from low and high fertilizers to organic amendment; similarly, the coloration of the wheat spikelet at maturity changes in that sequence. Although many soil organisms are responsible for disease or damage to crops, living things in the soil are responsible for many functions in agricultural soils. Thaumarchaeota is known to contribute to ammonia oxidation [87], which is of paramount importance in the nitrogen cycle [86,88], and its abundance was reduced by fertilizer application in the bulk soil [86]. Several Pseudomonas species (Proteobacteria) have the ability to use glucose, which gives them a competitive advantage over microorganisms that do not have the ability to use glucose [89]. Thus, the bacterial community structure 
may be a powerful biological soil health indicator. However, the literature lacks studies dealing with information on the effects of fertilizer applications on the root of the wheat microbiome and are still rare on the wheat spikelet. Bacteria associated with root and leaves, according to Bulgarelli et al. [90], were defined by relatively few bacterial phyla, which are Actinobacteria, Bacteroidetes, Firmicutes, and Proteobacteria. Similarly, Iffis et al. [91] also found a higher abundance of these phyla in plant root samples [91]. Nevertheless, bacterial communities at the phylum composition of leaf and root microbiota provide indirect pathogen protection, and the most important in bulk and rhizosphere [90]. Our results also show that the higher abundance of Proteobacteria, Bacteroidetes, and Actinobacteria was observed in the root and the wheat spikelet. Our results also show that the effect of organic matter and biochar amendments significantly increased soil properties, including $\mathrm{NH}_{4}{ }^{+}, \mathrm{AK}, \mathrm{AP}$, and TN concentrations than inorganic amendments in the rhizosphere. These results were inconsistent with [42] but were supported by most studies on alkaline soil [76,77]. Furthermore, CCA analysis showed that the bacterial community composition had a correlation with soil properties in both bulk soil $(\mathrm{pH})$ and rhizosphere $\left(\mathrm{NH}_{4}\right)$. Xu et al. [15] found no significant correlation between the phylum abundance and soil properties [15], while other studies show that $\mathrm{N}$ fertilizers were the main factors influencing soil bacterial biodiversity [20,61]. We observed that FO, FL, FH, and OM treatment nutrients were associated less with the bacterial structure than those of the BC. This is in line with the expectations that $\mathrm{BC}$ has been shown to not only improve soil properties but also change soil biological properties [63-65]. After the CCA analysis, nutrients from FO, FL, FH, and OM treatments were associated less than those in $\mathrm{BC}$ with the bacterial structure. These changes show that there is a strong relationship between the properties of the soil under $\mathrm{BC}$ application and the relative abundance of the bacterial community. The results suggest that the effects of soil amendment on bacterial community composition depend mainly on the ecological environment of the soil and play a long-term role in soil fertility. Furthermore, we found that the soil amendments increased the abundance of Bacteroidetes, Acidobacteria, and Actinobacteria and decreased the abundance of Proteobacteria after FH, OM, and BC application except in roots which show the opposite effect. Meanwhile, the degree of variation in abundance was more pronounced for $\mathrm{OM}$ and $\mathrm{BC}$ application due to the increased soil fertility.

\section{Conclusions}

This study showed that organic and mineral fertilization significantly changed soil enzyme activities and bacterial communities in bulk soil, rhizosphere soil, wheat roots, and spikelets. The rhizosphere compartment showed a greater increase in these parameters. The bacterial communities were dominated by Proteobacteria, Actinobacteria, Bacteroidetes, Acidobacteria, and Thaumarchaeota. Nevertheless, these phyla deferred, showing significant differences between compartments. Bacterial diversity was lower in wheat roots and evenlower in spikelet, as compared with soil and rhizosphere. Our results showed significant correlations between soil properties ( $\mathrm{pH}$ in bulk soil and $\mathrm{NH}_{4}{ }^{+}$in rhizosphere) and the bacterial community structure. Organic amendments improved the water retention capacity of the soil and increased the activities of acid phosphatase, $\beta-1,4-N$-acetyl-glucosaminidase, and phenol oxidase, while inorganic fertilizer regimes lowered soil $\mathrm{pH}$ towards neutral capable of promoting the assimilability of soil nutrients. Furthermore, these results suggested that manure and biochar are better than mineral fertilization regimes in improving the potential bacterial functions of both roots and above-ground organs of wheat.

Author Contributions: Conceptualization, K.Y., B.Z., and F.F.; methodology, all; validation, K.Y. and F.F.; formal analysis, A.A., Z.-X.T., and A.S.; resources, B.Z. and F.F; data curation, all; writing-original draft preparation, A.A.; visualization, K.Y.; funding acquisition, B.Z., K.Y., and F.F. All authors have read and agreed to the published version of the manuscript.

Funding: The research was supported by the National Key Research and Development Program of China (2016YFD0200109, 2019YFD1002000), cooperation grant CSC No. 2017GBJ008522, Fundamental Research Funds for Central Non-profit Scientific Institution (No. 1610132019021 and 1610132019011), and Modern Agricultural Industry Technology System of China (CARS-04-PS13).

Conflicts of Interest: The authors declare no conflict of interest. 


\section{References}

1. Altieri, M.A. The ecological role of biodiversity in agroecosystems. Agric. Ecosyst. Environ. 1999, 74, 19-31. [CrossRef]

2. Wang, Z.; Liu, Y.; Zhao, L.; Zhang, W.; Liu, L. Change of soil microbial community under long-term fertilization in a reclaimed sandy agricultural ecosystem. Peer] 2019, 7, 1-21. [CrossRef]

3. Flandroy, L.; Poutahidis, T.; Berg, G.; Clarke, G.; Dao, M.C.; Decaestecker, E.; Furman, E.; Haahtela, T.; Massart, S.; Plovier, H.; et al. The impact of human activities and lifestyles on the interlinked microbiota and health of humans and of ecosystems. Sci. Total Environ. 2018, 627, 1018-1038. [CrossRef] [PubMed]

4. Suleiman, A.K.A.; Manoeli, L.; Boldo, J.T.; Pereira, M.G.; Roesch, L.F.W. Shifts in soil bacterial community after eight years of land-use change. Syst. Appl. Microbiol. 2013, 36, 137-144. [CrossRef] [PubMed]

5. Sun, R.; Zhang, X.X.; Guo, X.; Wang, D.; Chu, H. Bacterial diversity in soils subjected to long-term chemical fertilization can be more stably maintained with the addition of livestock manure than wheat straw. Soil Biol. Biochem. 2015, 88, 9-18. [CrossRef]

6. Tiemann, L.K.; Grandy, A.S.; Atkinson, E.E.; Marin-Spiotta, E.; Mcdaniel, M.D. Crop rotational diversity enhances belowground communities and functions in an agroecosystem. Ecol. Lett. 2015, 18, 761-771. [CrossRef]

7. D'Acunto, L.; Andrade, J.F.; Poggio, S.L.; Semmartin, M. Diversifying crop rotation increased metabolic soil diversity and activity of the microbial community. Agric. Ecosyst. Environ. 2018, 257, 159-164. [CrossRef]

8. Juan, L.I.; Bing-Qiangl, Z.; Xiu-Yingl, L.I.; Rui-Bol, J.; Bing, S.H. Effects of Long-Term Combined Application of Organic and Mineral Fertilizers on Microbial Biomass, Soil Enzyme Activities and Soil Fertility. Agric. Sci. China 2008, 7, 336-343. [CrossRef]

9. Garciá-Orenes, F.; Morugań-Coronado, A.; Zornoza, R.; Scow, K. Changes in soil microbial community structure influenced by agricultural management practices in a Mediterranean agro-ecosystem. PLoS ONE 2013, 8, e80522. [CrossRef]

10. Kallenbach, C.M.; Wallenstein, M.D.; Schipanksi, M.E.; Stuart Grandy, A. Managing agroecosystems for soil microbial carbon use efficiency: Ecological unknowns, potential outcomes, and a path forward. Front. Microbiol. 2019, 10, 1-8. [CrossRef]

11. Cai, F.; Pang, G.; Li, R.X.; Li, R.; Gu, X.L.; Shen, Q.R.; Chen, W. Bioorganic fertilizer maintains a more stable soil microbiome than chemical fertilizer for monocropping. Biol. Fertil. Soils 2017, 53, 861-872. [CrossRef]

12. Cai, A.; Xu, M.; Wang, B.; Zhang, W.; Liang, G.; Hou, E. Manure acts as a better fertilizer for increasing crop yields than synthetic fertilizer does by improving soil fertility. Soil Tillage Res. 2019, 189, 168-175. [CrossRef]

13. Okore, C.; Ogechukwu, M.; Bright, O.; Assumpta, U.; Agaptus, O.; Uloma, N.; Chimahhalam, A. Effects of NPK fertilizer on soil enzymes and micro biota. GRF Davos Planet@Risk 2014, 2, 249-254.

14. Geisseler, D.; Scow, K.M. Long-term effects of mineral fertilizers on soil microorganisms-A review. Soil Biol. Biochem. 2014, 75, 54-63. [CrossRef]

15. Xu, L.; Yi, M.; Yi, H.; Guo, E.; Zhang, A. Manure and mineral fertilization change enzyme activity and bacterial community in millet rhizosphere soils. World J. Microbiol. Biotechnol. 2018, 34, 1-13. [CrossRef]

16. Holík, L.; Hlisnikovský, L.; Honzík, R.; Trögl, J.; Burdová, H.; Popelka, J. Soil microbial communities and enzyme activities after long-term application of inorganic and organic fertilizers at different depths of the soil profile. Sustainability 2019, 11, 3251. [CrossRef]

17. Wang, W.; Luo, X.; Chen, Y.; Ye, X.; Wang, H.; Cao, Z.; Ran, W.; Cui, Z. Succession of composition and function of soil bacterial communities during key rice growth stages. Front. Microbiol. 2019, 10, 1-11. [CrossRef]

18. Chang, E.; Chung, R.; Tsai, Y. Effect of different application rates of organic fertilizer on soil enzyme activity and microbial population. Soil Sci. Plant Nutr. 2017, 53, 132-140. [CrossRef]

19. Wang, Q.; Ma, M.; Jiang, X.; Guan, D.; Wei, D.; Zhao, B. Impact of 36 years of nitrogen fertilization on microbial community composition and soil carbon cycling-related enzyme activities in rhizospheres and bulk soils in northeast China. Appl. Soil Ecol. 2019, 136, 148-157. [CrossRef]

20. Van der Bom, F.; Nunes, I.; Sophie, N.; Hansen, V.; Bonnichsen, L.; Magid, J.; Nybroe, O.; Stoumann, L. Long-term fertilisation form, level and duration affect the diversity, structure and functioning of soil microbial communities in the field. Soil Biol. Biochem. 2018, 122, 91-103. [CrossRef]

21. Badji, A. Effects of Biochar on Microbiological Activities of Soil under Strong Nitrogen Inputs (Gardening); Master 2: Biotechnol; Plant and Microbial, University Cheikh Anta Diop of Dakar: Dakar, Senegal, 2011; pp. 1-60. 
22. Latini, A.; Bacci, G.; Teodoro, M.; Gattia, D.M.; Bevivino, A.; Trakal, L. The impact of soil-applied biochars from different vegetal feedstocks on durum wheat plant performance and rhizospheric bacterial microbiota in low metal-contaminated soil. Front. Microbiol. 2019, 10, 1-20. [CrossRef] [PubMed]

23. Elzobair, K.A.; Stromberger, M.E.; Ippolito, J.A.; Lentz, R.D. Contrasting effects of biochar versus manure on soil microbial communities and enzyme activities in an Aridisol. Chemosphere 2016, 142, 145-152. [CrossRef] [PubMed]

24. Sandhu, S.; Sekaran, U.; Ozlu, E.; Hoilett, N.O.; Kumar, S. Short-term impacts of biochar and manure application on soil labile carbon fractions, enzyme activity, and microbial community structure. Biochar 2019, 1, 271-282. [CrossRef]

25. Novak, J.M.; Busscher, W.J.; Watts, D.W.; Amonette, J.E.; Ippolito, J.A.; Lima, I.M.; Gaskin, J.; Das, K.C.; Steiner, C.; Ahmedna, M.; et al. Biochars impact on soil-moisture storage in an ultisol and two aridisols. Soil Sci. 2012, 177, 310-320. [CrossRef]

26. Ullah, M.S.; Islam, M.S.; Islam, M.A.; Haque, T. Effects of organic manures and chemical fertilizers on the yield of brinjal and soil properties. J. Bangladesh Agric. Univ. 2008, 6, 271-276. [CrossRef]

27. Balasubramanian, A. Soil Microorganisms. Univ. Mysore 2017. [CrossRef]

28. Zhang, Y.; Shen, H.; He, X.; Thomas, B.W.; Lupwayi, N.Z.; Hao, X.; Thomas, M.C.; Shi, X. Fertilization shapes bacterial community structure by alteration of soil pH. Front. Microbiol. 2017, 8, 1-11. [CrossRef]

29. Liu, Z.; Rong, Q.; Zhou, W.; Liang, G. Effects of inorganic and organic amendment on soil chemical properties, enzyme activities, microbial community and soil quality in yellow clayey soil. PLoS ONE 2017, 12, e0172767. [CrossRef]

30. Fan, K.; Cardona, C.; Li, Y.; Shi, Y.; Xiang, X.; Shen, C.; Wang, H.; Gilbert, J.A.; Chu, H. Rhizosphere-associated bacterial network structure and spatial distribution differ significantly from bulk soil in wheat crop fields. Soil Biol. Biochem. 2017, 113, 275-284. [CrossRef]

31. Donn, S.; Kirkegaard, J.A.; Perera, G.; Richardson, A.E.; Watt, M. Evolution of bacterial communities in the wheat crop rhizosphere. Environ. Microbiol. 2015, 17, 610-621. [CrossRef]

32. Schirawski, J.; Perlin, M.H. Plant-Microbe Interaction 2017-The Good, the Bad and the Diverse. Int. J. Mol. Sci. 2018, 19, 1374. [CrossRef] [PubMed]

33. Suleiman, B.; Muhammad, B.L.; Jakada, B.H.; Vyas, N.L. Rhizosphere Microbiome and Plant Nutrition. Int. J. Emerg. Trends Sci. Technol. 2015, 2, 3208-3216. [CrossRef]

34. Smalla, K.; Wieland, G.; Buchner, A.; Zock, A.; Parzy, J.; Kaiser, S.; Roskot, N.; Heuer, H.; Berg, G. Bulk and rhizosphere soil bacterial communities studied by denaturing gradient gel electrophoresis: Plant-dependent enrichment and seasonal shifts revealed. Appl. Environ. Microbiol. 2001, 67, 4742-4751. [CrossRef]

35. Hirsch, P.R.; Mauchline, T.H. Who's who in the plant root microbiome? Nat. Biotechnol. 2012, 30, 961-962. [CrossRef] [PubMed]

36. Chen, S.; Waghmode, T.R.; Sun, R.; Kuramae, E.E.; Hu, C.; Liu, B. Root-associated microbiomes of wheat under the combined effect of plant development and nitrogen fertilization. Microbiome 2019, 7, 136. [CrossRef]

37. Langenheder, S.; Lindstro, E.S.; Tranvik, L.J. Structure and function of bacterial communities emerging from different sources under identical conditions. Appl. Environ. Microbiol. 2006, 72, 212-220. [CrossRef]

38. Nannipieri, P.; Ascher, J.; Ceccherini, M.T.; Landi, L.; Pietramellara, G.; Renella, G. Microbial diversity and soil functions. Eur. J. Soil Sci. 2017, 68, 12-26. [CrossRef]

39. Zhu, J.; Peng, H.; Ji, X.; Li, C.; Li, S. Effects of reduced inorganic fertilization and rice straw recovery on soil enzyme activities and bacterial community in double-rice paddy soils. Eur. J. Soil Biol. 2019, 94, 103116. [CrossRef]

40. Wang, J.; Song, Y.; Ma, T.; Raza, W.; Li, J.; Howland, J.G.; Huang, Q.; Shen, Q. Impacts of inorganic and organic fertilization treatments on bacterial and fungal communities in a paddy soil. Appl. Soil Ecol. 2017, 112, 42-50. [CrossRef]

41. Xu, N.; Tan, G.; Wang, H.; Gai, X. Effect of biochar additions to soil on nitrogen leaching, microbial biomass and bacterial community structure. Eur. J. Soil Biol. 2016, 74, 1-8. [CrossRef]

42. Wang, Q.; Jiang, X.; Guan, D.; Wei, D.; Zhao, B.; Ma, M.; Chen, S.; Li, L.; Cao, F.; Li, J. Long-term fertilization changes bacterial diversity and bacterial communities in the maize rhizosphere of Chinese Mollisols. Appl. Soil Ecol. 2018, 125, 88-96. [CrossRef] 
43. Schmidt, J.E.; Kent, A.D.; Brisson, V.L.; Gaudin, A.C.M. Agricultural management and plant selection interactively affect rhizosphere microbial community structure and nitrogen cycling. Microbiome 2019, 7, 1-18. [CrossRef] [PubMed]

44. Jingjing, S.; Jiaheng, M.; Xiaoying, W.; Cheng, W.; Jun, Y. Microorganism quantity and enzyme activities in wheat field subjected to different nitrogen fertilizer rate. Open Biotechnol. J. 2015, 9, 204-208. [CrossRef]

45. Akça, M.O.; Naml, A. Effects of poultry litter biochar on soil enzyme activities and tomato, pepper and lettuce plants growth. Eurasian J. Soil Sci. 2015, 4, 161-168. [CrossRef]

46. Jacoby, R.; Peukert, M.; Succurro, A.; Koprivova, A.; Kopriva, S. The role of soil microorganisms in plant mineral nutrition-Current knowledge and future directions. Front. Plant Sci. 2017, 8, 1-19. [CrossRef]

47. OlumuyiwaIdowu, O.; Olajire-Ajayi, B.; Dada, O.; Wahab, O. Effects of fertilizers on soil's microbial growth and populations: A review. Am. J. Eng. Res. 2015, 4, 52-61.

48. Xiao, S.; You, H.; You, W.; Liu, J.; Cai, C.; Wu, J.; Ji, Z.; Zhan, S.; Hu, Z.; Zhang, Z.; et al. Rhizosphere and bulk soil enzyme activities in a Nothotsuga longibracteata forest in the Tianbaoyan National Nature Reserve, Fujian Province, China. J. For. Res. 2016, 28, 521-528. [CrossRef]

49. Mei, J.; Li, Z.; Sun, L.; Gui, H.; Wang, X. Assessment of heavy metals in the urban river sediments in Suzhou city, northern Anhui Province, China. Procedia Environ. Sci. 2011, 10, 2547-2553. [CrossRef]

50. Molina, L.R. Standard Operating Procedure Available Phosphorus (Olsen Phosphorus); International Rice Research Institute (IRRI): Los Baños, Philippines, 2011; Volume 3, pp. 1-8.

51. Saiya-cork, K.R.; Sinsabaugh, R.L.; Zak, D.R. The effects of long term nitrogen deposition on extracellular enzyme activity in an Acer saccharum forest soil. Soil Biol. Biochem. 2002, 34, 1309-1315. [CrossRef]

52. Deforest, J.L. The influence of time, storage temperature, and substrate age on potential soil enzyme activity in acidic forest soils using MUB-linked substrates and L-DOPA. Soil Biol. Biochem. 2009, 41, 1180-1186. [CrossRef]

53. Sinsabaugh, R.L.; Reynolds, H.; Long, T.M. Rapid assay for amidohydrolase (urease) activity in environmental samples. Soil Biol. Biochem. 2000, 32, 2095-2097. [CrossRef]

54. Marx, M.; Wood, M.; Jarvis, S.C. A microplate fluorimetric assay for the study of enzyme diversity in soils. Soil Biol. Biochem. 2001, 33, 1633-1640. [CrossRef]

55. Allison, S. Fluorimetric and oxidative enzyme assay protocol. Enzyme 2012, 1-6. Available online: https: //allison.bio.uci.edu/protocols/fluorimetricenzymeprotocol.pdf (accessed on 7 July 2018).

56. Xu, Z.; Yu, G.; Zhang, X.; Ge, J.; He, N.; Wang, Q.; Wang, D. The variations in soil microbial communities, enzyme activities and their relationships with soil organic matter decomposition along the northern slope of Changbai Mountain. Appl. Soil Ecol. 2014, 86, 19-29. [CrossRef]

57. Ai, C.; Zhang, S.; Zhang, X.; Guo, D.; Zhou, W.; Huang, S. Distinct responses of soil bacterial and fungal communities to changes in fertilization regime and crop rotation. Geoderma 2018, 319, 156-166. [CrossRef]

58. Assays, F.E.; Samples, M.; Allison, S.; Boulder, C.; Biology, S.; N-acetyl-, M. Fluorimetric enzyme assay protocol for marine samples. Enzyme 2009, 2-6. Available online: https://allison.bio.uci.edu/protocols/ enzymeprotocolmarine100311.pdf (accessed on 31 July 2018).

59. Fan, F.; Li, Z.; Wakelin, S.A.; Yu, W.; Liang, Y. Mineral fertilizer alters cellulolytic community structure and suppresses soil cellobiohydrolase activity in a long-term fertilization experiment. Soil Biol. Biochem. 2012, 55, 70-77. [CrossRef]

60. Fan, F.; Yang, Q.; Li, Z.; Liang, Y. pH, phosphorus and C: P dominantly control the community structure of bacteria, fungi, archaea and nitrogen-cycling-associated microbes in an arable chernozem. In Proceedings of the 19th World Congress of Soil Science, Soil Solutions for a Changing World, Brisbane, Australia, 1-6 August 2010; pp. 25-28.

61. Dimitrov, M.R.; Veraart, A.J.; de Hollander, M.; Smidt, H.; Van Veen, J.A.; Kuramae, E.E. Successive DNA extractions improve characterization of soil microbial communities. Peer] 2017, 1, 1-29. [CrossRef]

62. Aerts, J.W.; van Spanning, R.J.M.; Flahaut, J.; Molenaar, D.; Bland, P.A.; Genge, M.J.; Ehrenfreund, P.; Martins, Z. Microbial communities in sediments from four mildly acidic ephemeral salt lakes in the Yilgarn Craton (Australia)-Terrestrial Analogs to Ancient Mars. Front. Microbiol. 2019, 10, 1-19. [CrossRef]

63. Fan, F.; Yu, B.; Wang, B.; George, T.S.; Yin, H.; Xu, D.; Li, D.; Song, A. Microbial mechanisms of the contrast residue decomposition and priming effect in soils with different organic and chemical fertilization histories. Soil Biol. Biochem. 2019, 135, 213-221. [CrossRef] 
64. Edgar, R.C. UPARSE: Highly accurate OTU sequences from microbial amplicon reads. Nat. Methods 2013, 10, 996-998. [CrossRef]

65. Edgar, R.C.; Haas, B.J.; Clemente, J.C.; Quince, C.; Knight, R. UCHIME improves sensitivity and speed of chimera detection. Bioinformatics 2011, 27, 2194-2200. [CrossRef]

66. Edgar, R.C. Search and clustering orders of magnitude faster than BLAST. Bioinformatics 2010, 26, $2460-2461$. [CrossRef] [PubMed]

67. Wang, Q.; Garrity, G.M.; Tiedje, J.M.; Cole, J.R. Naïve Bayesian classifier for rapid assignment of rRNA sequences into the new bacterial taxonomy. Appl. Environ. Microbiol. 2007, 73, 5261-5267. [CrossRef] [PubMed]

68. Lin, W.; Lin, M.; Zhou, H.; Wu, H.; Li, Z.; Lin, W. The effects of chemical and organic fertilizer usage on rhizosphere soil in tea orchards. PLoS ONE 2019, 14, e0217018. [CrossRef] [PubMed]

69. Whalley, W.R.; Riseley, B.; Leeds-Harrison, P.B.; Bird, N.R.A.; Leech, P.K.; Adderley, W.P. Structural differences between bulk and rhizosphere soil. Eur. J. Soil Sci. 2005, 56, 353-360. [CrossRef]

70. Carminati, A.; Moradi, A.B.; Vetterlein, D.; Vontobel, P.; Lehmann, E.; Weller, U.; Vogel, H.-J.; Oswald, S.E. Dynamics of soil water content in the rhizosphere. Plant Soil 2010, 332, 163-176. [CrossRef]

71. Zhalnina, K.; Dias, R.; de Quadros, P.D.; Mcgrath, S.P.; Hirsch, P.R.; Triplett, E.W. Soil pH determines microbial diversity and composition in the park grass experiment. Soil Microbiol. 2015, 63, 395-406. [CrossRef]

72. Yang, F.; Wu, J.; Zhang, D.; Chen, Q.; Zhang, Q.; Cheng, X. Soil bacterial community composition and diversity in relation to edaphic properties and plant traits in grasslands of southern China. Appl. Soil Ecol. 2018, 128, 43-53. [CrossRef]

73. Moreno-Espíndola, I.P.; Ferrara-Guerrero, M.J.; Luna-Guido, M.L.; Ramírez-Villanueva, D.A.; de León-Lorenzana, A.S.; Gómez-Acata, S.; González-Terreros, E.; Ramírez-Barajas, B.; Navarro-Noya, Y.E.; Sánchez-Rodríguez, L.M.; et al. The Bacterial community structure and microbial activity in a traditional organic milpamarming system under different soil moisture conditions. Front. Microbiol. 2018, 9, 1-19. [CrossRef]

74. Caldwell, B.A. Enzyme activities as a component of soil biodiversity: A review. Pedobiologia 2005, 49, 637-644. [CrossRef]

75. Shi, J.; Yuan, X.; Lin, H.; Yang, Y.; Li, Z. Differences in soil properties and bacterial communities between the rhizosphere and bulk soil and among different production areas of the medicinal plant fritillaria thunbergii. Int. J. Mol. Sci. 2011, 12, 3770-3785. [CrossRef] [PubMed]

76. Ai, C.; Liang, G.; Sun, J.; Wang, X.; Zhou, W. Responses of extracellular enzyme activities and microbial community in both the rhizosphere and bulk soil to long-term fertilization practices in a fluvo-aquic soil. Geoderma 2012, 173-174, 330-338. [CrossRef]

77. Chaudhary, D.R.; Gautam, R.K.; Yousuf, B.; Mishra, A.; Jha, B. Nutrients, microbial community structure and functional gene abundance of rhizosphere and bulk soils of halophytes. Appl. Soil Ecol. 2015, 91, 16-26. [CrossRef]

78. Liang, G.; Cai, A.; Wu, H.; Wu, X.; Houssou, A.A.; Ren, C.; Wang, Z.; Gao, L.; Wang, B.; Li, S.; et al. Soil biochemical parameters in the rhizosphere contribute more to changes in soil respiration and its components than those in the bulk soil under nitrogen application in croplands. Plant Soil 2019, 435, 111-125. [CrossRef]

79. Elsoury, H.A.; Shouman, A.E.; Elkony, H.M. Soil enzymes and microbial activity as influenced by tillage and fertilization in wheat production. Egypt J. Soil. Sci. 2015, 55, 53-65. [CrossRef]

80. Zheng, W.; Gong, Q.; Zhao, Z.; Liu, J.; Zhai, B.; Wang, Z. Changes in the soil bacterial community structure and enzyme activities after intercrop mulch with cover crop for eight years in an orchard. Eur. J. Soil Biol. 2018, 86, 34-41. [CrossRef]

81. Zhang, L.; Chen, W.; Burger, M.; Yang, L.; Gong, P.; Wu, Z. Changes in Soil Carbon and Enzyme Activity as a Result of Different Long-Term Fertilization Regimes in a Greenhouse Field. PLoS ONE 2015, 10, e0118371. [CrossRef] [PubMed]

82. Guo, Q.; Yan, L.; Korpelainen, H.; Niinemets, Ü.; Li, C. Plant-plant interactions and N fertilization shape soil bacterial and fungal communities. Soil Biol. Biochem. 2019, 128, 127-138. [CrossRef]

83. De Almeida, R.F.; Naves, E.R.; Pinheiro, R. Soil quality: Enzymatic activity of soil $\beta$-glucosidase. Glob. J. Agric. Res. Rev. 2015, 3, 146-150.

84. Hojati, S.; Nourbakhsh, F. Distribution of $\beta$-glucosidase activity within aggregates of a soil amended with organic fertilizers. Am. J. Agric. Biol. Sci. 2009, 4, 179-186. [CrossRef] 
85. Soman, C.; Li, D.; Wander, M.M.; Kent, A.D. Long-term fertilizer and crop-rotation treatments differentially affect soil bacterial community structure. Plant Soil 2017, 413, 145-159. [CrossRef]

86. Nelkner, J.; Henke, C.; Lin, T.W.; Pätzold, W.; Hassa, J.; Jaenicke, S.; Grosch, R.; Pühler, A.; Sczyrba, A.; Schlüter, A. Effect of long-term farming practices on agricultural soil microbiome members represented by metagenomically assembled genomes (MAGs) and their predicted plant-beneficial genes. Genes 2019, 10, 424. [CrossRef] [PubMed]

87. Müller, O.; Wilson, B.; Paulsen, M.L.; Ruminska, A.; Armo, H.R.; Bratbak, G.; Øvreås, L. Spatiotemporal dynamics of ammonia-oxidizing Thaumarchaeota in Distinct Arctic water masses. Front. Microbiol. 2018, 9 , 1-13. [CrossRef] [PubMed]

88. He, H.; Zhen, Y.; Mi, T.; Fu, L.; Yu, Z. Ammonia-oxidizing archaea and bacteria differentially contribute to ammonia oxidation in sediments from adjacent waters of Rushan Bay, China. Front. Microbiol. 2018, 9, 1-14. [CrossRef]

89. Meena, M.; Swapnil, P.; Zehra, A.; Aamir, M.; Dubey, M.K.; Goutam, J.; Upadhyay, R.S. Beneficial microbes for disease suppression and plant growth promotion. In Plant-Microbe Interactions in Agro-Ecological Perspectives; Springer: Singapore, 2017; Volume 2, pp. 395-432. ISBN 9789811065934.

90. Bulgarelli, D.; Schlaeppi, K.; Spaepen, S.; Ver, E.; van Themaat, L.; Schulze-lefert, P. Structure and functions of the bacterial microbiota of plants. Annu. Rev. Plant Biol. 2013, 64, 807-838. [CrossRef]

91. Iffis, B.; St-Arnaud, M.; Hijri, M. Petroleum contamination and plant identity influence soil and root microbial communities while AMF spores retrieved from the same plants possess markedly different communities. Front. Plant Sci. 2017, 8, 1-16. [CrossRef] [PubMed]

(C) 2020 by the authors. Licensee MDPI, Basel, Switzerland. This article is an open access article distributed under the terms and conditions of the Creative Commons Attribution (CC BY) license (http://creativecommons.org/licenses/by/4.0/). 